\title{
IS THERE A DIFFERENCE BETWEEN THE CAPABILITIES OF FOREIGN AND DOMESTIC MANAGERS? A CASE STUDY AT FIVE AND FOUR STAR HOTELS IN AQABA - JORDAN
}

\author{
QuSay QAHTAN KHALEEFAH* \\ Al Balqa Applied University / Aqaba University College- Jordan, Department of Tourism \& Hotel Sciences, e-mail: q.khaleefa@bau.edu.jo
}

\begin{abstract}
Citation: Khaleefah Qusay, Q. (2020). IS THERE A DIFFERENCE BETWEEN THE CAPABILITIES OF FOREIGN AND DOMESTIC MANAGERS? A CASE STUDY AT FIVE AND FOUR STAR HOTELS IN AQABA - JORDAN. GeoJournal of Tourism and Geosites, 30(2spl), 861-867. https://doi.org/10.30892/gtg.302spl11-515
\end{abstract}

\begin{abstract}
The study investigated the actual practices dealing with foreign department managers' duties, and the possibility of employing these practices to support the domestic department managers in order to manage departments in the four and five star hotels in Aqaba-Jordan and the other Arab Countries. The study indicated that both of foreign and domestic managers have efficiency in their duties and skills. This study presented that there is no statistically significant differences between foreign and domestic manager in behavior, efficiency, and skills. The study recommended that the factors identify the right criteria in dealings adopted by foreign managers and their staff regarding the possibility of hiring these criteria to support the domestic managers to manage in the four and five star hotels in Aqaba -Jordan and the other Arab Countries.
\end{abstract}

Key words: Expatriate Managers, Domestic Managers, Behaviors, Capabilities, Hotels

\section{INTRODUCTION}

The process of development at the present time faces a stage of fundamental transformation in which human capital has become a source of services rather than a source of material productive capacities, and the years after the Second World War witnessed the beginning of this transformation in economically developed countries (Baum, 2019), that's left an impact on the structure of manpower, the results of this transformation have been enormous changes in the sectors that use manpower in the production process, as they require different types and levels of skills that are different from the above (Zaheer and Subramani, 2009). As the world rapidly turns towards civil society, which is accompanied by the escalation, growth and diversification of human needs, it requires a transformation into a knowledge-based economy, with which it is necessary to expand the base of high-level technology services, Xu et al., (2018) explained that this transformation in the process of building economic growth and development requires a different human workforce, in terms of the level of education, training and experience in the fields of specialization.Globalization has played a big role that entry the multinational organization in the Jordanian Hotel industry. The most of international hotels chains are managed by expatriate managers in Jordan. The Hashemite Kingdom of Jordan is located in center of Middle East, with population around ten millions, with insufficient supplies of water, oil, and other natural resources. Other economic challenges include high rates of unemployment and underemployment, budget deficits, and government debt.

The Jordanian economy depends basically on service industry and the revenue of immigrant Jordanian workers in the Gulf area and other oil countries in the region. The hotel industry in Jordan is one of the most three important industries that constitute the driving force for the national economy. These industries are (communications industry, information technology industry, and tourism industry) and because of tourism industry importance in Jordan as one of the developing countries to develop its economy, competition has intensified to attract more tourists and increase its market share of the global tourism, as the tourism industry is unique as the fastest, most developed and the most developed among these industries, as the trained domestic competencies have the greatest impact through the efforts made in this field to achieve the tourism renaissance that is commensurate with the constituents of tourists Natural and human tourist attractions in Jordan.

Therefore Hospitality industry is considered one of the main resources for the Jordanian economy. In Aqaba, there are (55) hotels as a total of all classifications from (1 to 5 stars), (8) five stars hotels and (5) four stars hotels with total capacity (3685 Rooms) and the number of employees is (1899). In Jordan approximately (20951) employees are working in Hotel sector according to the official statistics in year 2019 (Ministry of Tourism \& Antiquities, 2019). Consequently, the purpose of this study was to examine the differences between the performance, skill, efficiency, effectiveness and work ethics of foreign and domestic managers, specifically, the study was directed by the following objectives:

1- Demonstrates that there are no differences between the performance, skills and work ethics of foreign and domestic managers.

2- Presents the efficiency and effectiveness of domestic managers of four and five star hotels at Aqaba City.

3- Addresses some of the reluctances of domestic managers that make foreign managers better and more favorable than them.

\section{Literature review and questions development}

According to Dunning and Lundan (2008) conducted study in the quality of hospitality in five star hotels under a management of foreign managers, that argued the positive impact of foreign managers on the hotels and the quality of their services. They found the significance of using foreign managers to improve the performance of domestic managers, therefore domestic managers will gain new knowledge and experience from them. The TeVelde and Morrissey (2002) study was conducted in South Africa and aimed to investigate the level of standards for hotel services which provide them the opportunity to be trained by foreign managers of the expertise and high skills and the extent of the effect of those on the local employee. The study showed the extent of benefit from transfer of knowledge, experience and training of the hotel management patterns which in turn have led to raise the standards of service quality of the hotel.

Ashley and Roe (2002) argued that the employment of foreigners in the top management such as GM, Executive chef and other top management positions and how they transfer their knowledge to the domestic mangers. The study found that with chronological progress the foreign top management has been replaced with domestic management in the hotels; reducing the operational cost. Moreover, the study was conducted in Kenya and Tanzania. According to Gooze (1991), Jumaily (2010) the efficiency in work means in the capability of workers to 
complete their job within the standard time to achieve the desired objectives. Sweilem (1991); Hashim (1989) define job skills as the basic information that every employee must be familiar with performing it efficiently and effectively. The job behavior is one of the most important things that management is looking for. Moreover, it includes many personal motivational skills to succeed at work. The employees' need to have a strong character, leadership, capability of innovation and self-reliance, furthermore, the management looks for employees who are trusted to create job opportunities, develop work system and have capabilities to communicate with colleagues and clients (Alaak, 1999; Deisler, 1993; Werther, 1996; Hujaz, 2004; Bloom and Van Reenen, 2010; Ferraris et al., 2017). Many researchers debate that the managers must have many skills to do their job effectively and efficiently as the following (Rumi et al., 2006; Torrigton, 2002; Woods, 1995; Murthy, 2003; Denisi, 2005; Naschold, 2017; Fang et al., 2010; Kale, 2020):

- The effectiveness of Job: This includes the dimension of skills that promote the manager culture about the world of work and its field and job skills.

- The informational effectiveness: This dimension contains competencies that develop the capacity of manager in the use of technological development, the acquisition of positive trends and take advantage of them to get informational system.

- The effective personal: This dimension includes the competencies relating to some personal and social aspects of the manager, which represents his behavior and trends and assist in the completion of career growth; to deal with the work atmosphere positively.

The problem of the study is summarized by this question: Are the domestic managers in five and four star hotels having the capability to manage the departments as foreign managers?

There is a focuses paucity that necessity of employing domestic managers to manage four and five star hotels at Aqaba City in Hashemite Kingdom of Jordan. Moreover, the study was conducted to show the proper basis that foreign managers follow and how these bases could be used to support and improve the domestic managers and their ability to manage four and five star hotels.

Arab countries have sought during the past decades to achieve economic development through foreign investments in the tourism and hotel sector, to rely on solid international companies in creating tourism investments, especially in the hotel sector, and to start relying on foreign labor in managing these hotels in order to make investments successful and achieve a return on the investment which is proportional to the size of those investments. Manoharan et al. (2019) said these investments were distinguished by the large use of foreign labor, especially in the top and some middle departments, in addition to labors in the field of food and beverage services, in particular the bar department. Haendel (2019) see the foreign employment has created challenges faced by Arab societies, represented by the high number of foreign labors in the hotel sector and the difficulty of replacing domestic labor in managing hotel departments, especially operational ones. After it was relied almost completely on understanding the tourism and hotel market and setting plans and strategies to develop work and raise the rates of occupancy in hotels. Baum (2019) said that after the expansion of the unemployment space among the members of the Arab countries and the deteriorating economic conditions of the Arab countries and the insistence of the governments to provide employment opportunities for the members of the domestic community for those countries, the urgent need emerged to study the possibility of replacing the domestic labor with foreign labors in managing the various hotel departments in order to achieve the following:

\section{Unemployment Treatment:}

Despite the great development that the Arab countries have enjoyed in recent decades, Baert and Verhaest (2019) said that most studies indicate that there is an unemployment phenomenon among the domestic labors of these countries as a negative phenomenon as a result of dependence on foreign labor. In contrast domestic labor prefers to work in the government sector because of its job security and greater job privileges. Baert and Verhaest (2019) explain that after monitoring the subsequent callback, they find evidence of a larger stigma effect of unemployment than over education. The stigma effect of over education is found to occur for permanent contract jobs but not for temporary ones. Abo-Murad and Abdullah (2019) said that foreign employment has led to a multiplication of the economic problems experienced by the Arab countries, as the presence of unemployment as a result of employing foreign labor has led to an increase in the manifestations of fear and anxiety of the future among Arab governments and Arab youth who are on the seats of study in universities, as an excuse for not Providing job opportunities for them after they graduate. In light of the foregoing it became the Arab youth aspires to work outside the borders of their country in order to ensure employment opportunities, especially in the hotel and tourism sector, as the number of expatriates from the young Jordanian workers reached outside Jordan borders around (786.000) and this number constitutes $10.5 \%$ of total Jordanians labors, according to what was published in the Jordanian newspaper Al-Rai dated 4/7/2018. Therefore, Arab governments have endeavored to study the impact of foreign labor and try to replace domestic labor in order to strive seriously to achieve the following:

1- Making full use of the domestic human capabilities.

2- Dispense with foreign labors to avoid the size of external financial transfers.

The presence of 680 thousand migrant workers out of a million who do not have work permits, in Jordan, working in an illegal manner. Those with work permits among migrants reached 320 thousand, which caused an imbalance in the Jordanian labor market despite recent correction campaigns, indicating, that there are between 280 thousand and 300 thousand unemployed in Jordan, and that the total workforce reached 1.6 Million, while the unemployment rate in Jordan was $18.5 \%$.

Hence the importance of this study revolves around the preparation in advance for the replacement of domestic labors in the place of foreign labors, taking in their account the difference of skills and experiences for foreign labors, and whether the domestic employment in the case of substitution will enjoy the same skills and capabilities that can be done in the hotel sector?

\section{Reducing financial transfers to foreign labors:}

One of the most serious economic problems facing Arab countries is Remittances of foreign labors, and this may be due to two main remembers:

1-The increase of financial transfers.

2-The increase of foreign labors annually.

This indicates the urgent need for a rational economic policy in the labor market, that is not limited only to the question of replacing foreign labors with domestic labors, but also extends to the structure of the labor market in terms of wages, the nature of occupations, and methods of employment, especially in the private sector, and the impact of these policies on the volume of labor demands Foreign (Zaheer and Subramani, 2009). And the numbers of expatriate workers "raise the alarm bell on Jordan in terms of security, economic and social, while the unemployment rate among Jordanians is increasing," and these numbers confirm the existence of lack of organization and coordination between the relevant authorities in this regard. It is necessary to gradually have a national strategy to replace foreign with domestic labors. And the value of remittances from foreign labors transferred outside Jordan amounted to 1.8 billion dinars (Chairman of the Labor, Social Development and Population Committee of Jordan, 2018). 


\section{Reorganizing the economic structure:}

Dyer and Batnitzky (2010) saw that the increase in volume of foreign labor has led to a misallocation of the domestic labor force on the aspects of economic activity on the one hand, and on the labor market on the other hand, as it is easy to notice the fragmentation of labor markets in Arab countries into markets for domestic labors, and markets for foreign labors, mostly in the private sector , and each of these markets as Hoffman, (2019) says has working rules, levels of wages and benefits related to each market separately, which reflected negatively on the desire of the Jordanian domestic labors to work within the private hotel sector due to the work policy of the owners of the private hotel sector regarding the rate of wages, salaries, working hours and the rest of the concession $\mathrm{T}$ and other not only in the government sector are available.

\section{Involving women in the tourism and hotel sector:}

Khaleefah et al. (2018) said that the tourist awareness in Arab countries recedes on the concept of customs, traditions, religion and some inherited beliefs that Arab societies do not want women to engage in tourism and hotel work, due to several considerations related to society. The tourist awareness in Arab countries recedes on the concept of customs, traditions, religion and some inherited beliefs that Arab societies do not want women to engage in tourism and hotel work, due to several considerations related to society.

Richards and Martin (1983) explained that the customs and traditions come from religion, and this explains the correlation between them, as well as gender and religion; where some of community members reject working in hotels, due to mixing between the two genders at work, which may be forbidden by Islam, and there is a relationship between gender, customs and traditions, which imposes that the society looks lowly at women who work in the hotel field. The community, in terms of family, does not encourage engagement in hotel work. The families refuse to be sexually harassed by visitors and guests at the hotel. Linehan (2019) say "The family refuses that their members (especially females) work at hotels, because work may require staying outside their home", where this does not encourage the family to promote its members (especially females) to work at hotels, perhaps due to lack of cultural awareness, the customs and traditions, religion, and gender.

Khaleefah et al. (2018) suggested that the Arab governments should raise the awareness of the domestic community regarding many issues related to hotel work, such as the nature of hotel work and its sections, the fields of hotel work, especially for females, employment opportunities provided by this industry to the members of society, through various media, especially visual, workshops supported by the success stories of male and female labors in hotels, who have achieved success in the various fields of work (economic, career path and Social fields), demonstrating the economic importance of the tourism industry in general and hotels in particular, and the importance of hotels in terms of job size available in the next few years, through organizing events, conferences, workshops and seminars on a continuous basis, to include as many as possible members of the community, Moreover, enhancing the role of educational institutes through the Ministry of Higher Education via encouraging the students to study tourism and hospitality management and under studying the role of tourism industry in the economic in order to create awareness between the students about the importance of this industry and confront taboo culture through workshops for the high school students.

\section{Reducing government financial burdens:}

Arab governments will take additional financial responsibility that may contribute to putting pressure on the country's economy, including health, education, infrastructure, security, trade and agriculture due to the increasing number of foreign labors and their expatriate families, as well as an increase in food imports and consumer goods and services that will increase demand in the future due to the increase in foreign labor (Patunru and Uddarojat, 2015).

\section{Study Questions}

The study answers the following questions:

\section{Primary Questions}

a-Is a foreign manager more efficient and skilled than a domestic manager?

b-Is it possible to come up with a training program that is based on skills and work ethics? Is there a chance to reflect or apply these skills to domestic managers?

\section{Secondary Questions}

First. How much positive behavior do domestic managers have?

Second. How much efficiency do domestic managers have?

Third. How many skills do domestic managers have?

Fourth. How much positive behavior do foreign managers have?

Fifth. How much efficiency do foreign managers have?

Sixth. How many skills do foreign managers have?

Seventh. Are there any statistically significant differences between the behavior of domestic and foreign managers?

Eighth. Are there any statistically significant differences between the skills of domestic and foreign managers?

Ninth. Are there any statistically significant differences between the efficiency of domestic and foreign managers?

\section{MATERIALS AND METHODS}

\section{Data Collection}

Data was collected from the employees who work in the operational departments in the four and five star hotels at Aqaba City - Jordan. The samples consist of supervisors and executive managers of operational departments of four and five star hotels, who are ex perienced, and have worked under the supervision of foreign managers and domestic manager. This sample works under the supervision of international hotel chains in all Arab countries, and may be governed by the same working environment, customs and traditions in those coun tries.

\section{Questionnaire Development}

Capabilities of foreign and domestic managers was measured according to Xu et al., (2018), and positive behavior of foreign managers were measured according to Palthe (2004), Zaheer and Subramani (2009) model. On the other hand, efficiency was measured by using items adopted from Fu et al. (2012), Baum (2019) and Manoharan et al. (2019).

\section{Descriptive Analysis}

According to (Table 1), $58 \%$ of the respondents were males and the $42 \%$ were females. Moreover, $64 \%$ of the respondents had bachelor 
degrees, $20 \%$ had diplomas, $8 \%$ had no high school diplomas, $4 \%$ had high educations, and $4 \%$ had high school diplomas. In addition, $56 \%$ of the samples were executive administrator and $44 \%$ were supervisors.

Table 1. Number of Candidates and percentages for the Gender, Job Title and Education level

\begin{tabular}{|l|l|l|}
\hline Gender & Number of Candidates & Percentages\% \\
\hline Males & 29 & $58 \%$ \\
\hline Females & 21 & $42 \%$ \\
\hline Job Title & Number of Candidates & Percentages \\
\hline Supervisor & 22 & $\% 44$ \\
\hline Executive Manager & 28 & $\% 56$ \\
\hline Education Level & Number of Candidates & Percentages\% \\
\hline No High School Diploma & 4 & $8 \%$ \\
\hline College Diploma & 10 & $20 \%$ \\
\hline Bachelor Degree & 32 & $64 \%$ \\
\hline High School Diploma & 2 & $4 \%$ \\
\hline Higher Education & 2 & $4 \%$ \\
\hline
\end{tabular}

\section{RESULTS DISCUSSIONS}

First Question: How much positive behavior do domestic managers have?

According to table (2), it is clear that questions No. 1, 4, 8, 9, 15, 17, 18, 23, 25 and 29 had a mean that is above 2.5 and had a level of accuracy that is less than 0.05 , which means it is statistically significant and present in the domestic managers. From questions number 7,14 , 19 and 29, they had a mean that is above 2.5 but they had a level of accuracy that is above 0.05 which means it is not statistically significant and there is no significance level on the strategy of the manager being your boss during working hours and your friend outside of work. In addition, it demonstrates that the domestic manager does not reflect his/her personal problems on his/her way of treating his/her employees.

Lastly, for the other columns the mean was 2.84 and a level of accuracy that was 0.00 . This level is less than 0.05 therefore it has a significance level and the domestic managers have positive behavior.

Table 2. Mean, standard deviation, t-value and accuracy level of behavior in domestic managers

\begin{tabular}{|c|c|c|c|c|c|}
\hline Question Number & Question & Mean & Standard Deviation & T-Value & Level of Accuracy \\
\hline 1 & A domestic manager treats his/her employees equally & 2.8800 & 0.71 & 3.741 & 0.00 \\
\hline 4 & Language is not a barrier between domestic managers and employees & 3.0000 & 0.85 & 4.125 & 0.00 \\
\hline 7 & Domestic manager is your manager while working, not more & 2.7600 & 0.95 & 1.916 & 0.061 \\
\hline
\end{tabular}

Second Question: How much efficiency do domestic managers have?

According to the table number 3: Mean, standard deviation, $t$-value and accuracy level of efficiency in domestic manager. It appears that all of the questions had a mean that is above 2.5, and a level of accuracy that is less than 0.05 , which means that all of these columns are statistically significant and are present in the domestic managers. The total of the columns had a mean of 2.93 and level of accuracy that is 0.00. This level is less than 0.05 therefore it has a significance level and the domestic managers are efficient.

Table 3. Mean, standard deviation, t-value and accuracy level of efficiency in domestic managers

\begin{tabular}{|c|c|c|c|c|c|}
\hline Question Number & $\begin{array}{l}\text { Question } \\
\end{array}$ & Mean & Standard Deviation & T-Value & Level of Accuracy \\
\hline 3 & Domestic manager knows the details of the work of his employees. & 3.0400 & 0.72 & 5.250 & 0.00 \\
\hline 5 & Domestic manager is able to make the correct decisions at the right time & 2.9600 & 0.78 & 4.163 & 0.00 \\
\hline 11 & $\begin{array}{l}\text { Domestic manager is able to come up with new ideas and discuss } \\
\text { them with its employees }\end{array}$ & 2.9600 & 0.78 & 4.163 & 0.00 \\
\hline 13 & A domestic manager improves the employees by always training them & 2.8800 & 0.59 & 4.525 & 0.00 \\
\hline 20 & $\begin{array}{l}\text { A domestic manager supports any employees in need of financial or } \\
\text { emotional support }\end{array}$ & 2.8400 & 0.88 & 2.705 & 0.009 \\
\hline 21 & A domestic manager helps to develop the ideas of employees & 2.7600 & & 2.236 & 0.03 \\
\hline 24 & Effective leadership of employees to achieve the goals of hotel & 2.8400 & 0.82 & 2.856 & 0.006 \\
\hline 26 & A domestic manager makes predictions about future & 3.2400 & 0.84 & 8.852 & 0.00 \\
\hline 27 & $\begin{array}{l}\text { Domestic manager knows the bases and concepts of quality in the } \\
\text { hotel he/she manages }\end{array}$ & 2.9200 & 0.59 & 4.272 & 0.00 \\
\hline \multirow[t]{2}{*}{28} & $\begin{array}{l}\text { If a problem happened between you and your domestic manager, } \\
\text { he/she would try to solve it wisely and gently }\end{array}$ & 2.8800 & 0.69 & 3.081 & 0.003 \\
\hline & Total & 2.9320 & 0.87 & 5.244 & 0.00 \\
\hline
\end{tabular}

Third Question: How many skills do domestic managers have?

In table number 4 , it appears that all of the questions had a mean that is above 2.5 and a level of accuracy that is less than 0.05 , which means that all of these questions are statistically significant, and are present in the domestic managers. The total of the columns had a mean of 3.15 and level of accuracy that was 0.00 . This level is less than 0.05 therefore it has a significance level and the domestic managers are skilled.

Table 4. Mean, standard deviation, t-value and accuracy level of skills in domestic managers

\begin{tabular}{|c|c|c|c|c|c|}
\hline Question Number & Question & Mean Question & Standard Deviation & T-Value & Accuracy Level \\
\hline 2 & Domestic manager is able to deal with its employees directly & 2.8000 & 0.63 & 3.320 & 0.002 \\
\hline 6 & Domestic manager takes the opinions and ideas of employees seriously & 2.8400 & 0.68 & 3.531 & 0.001 \\
\hline 10 & Domestic manger respects the customs and traditions of domestic employees & 3.2400 & 0.59 & 8.852 & 0.00 \\
\hline 12 & $\begin{array}{l}\text { A domestic management keeps up with technology and opens new } \\
\text { opportunities associated with the new technology }\end{array}$ & 2.8800 & 0.71 & 3.741 & 0.00 \\
\hline 16 & A domestic manager encourages employees to advance academically & 3.0800 & 0.63 & 6.471 & 0.00 \\
\hline \multirow[t]{2}{*}{22} & A domestic manager manages his/her time wisely and he able to cope with stress & 3.4800 & 0.71 & 1.604 & 0.00 \\
\hline & Total & 3.1533 & 0.58 & 4.156 & 0.00 \\
\hline
\end{tabular}


Fourth Question: How much positive behavior do foreign managers have?

According to table number 5, it appears that all of the columns had a mean that is above 2.5 and a level of accuracy that is less than 0.05 , except for column (question) 4. This means that all of these columns are statistically significant and are present in foreign managers. Question 4, however, had a mean that is above 2.5, but its level of accuracy was above 0.05 which means it is not statistical ly significant and there is no significance level about language and it being a big barrier between the foreign managers and domestic employees. The total of the columns had a mean of 2.89 and a level of accuracy that was 0.00 . This level is less than 0.05 therefore it has a significance level and foreign managers have positive behavior.

Table 5. Mean, standard deviation, t-value and accuracy level of behavior in foreign managers

\begin{tabular}{|c|c|c|c|c|c|}
\hline Question Number & Question & Mean & Standard Deviation & T-Value & Accuracy Level \\
\hline 1 & A foreign manager treats his/her employees equally & 3.0800 & 0.69 & 5.900 & 0.00 \\
\hline 4 & Language is not a barrier between foreign managers and domestic employees & 2.6600 & 1.02 & 1.107 & 0.274 \\
\hline 7 & Foreign manager is your boss during working hours and your friend outside of work. & 3.0800 & 0.75 & 5.457 & 0.00 \\
\hline 9 & Foreign manager involves his/her employees in planning and developing the hotel & 3.0600 & 0.76 & 5.163 & 0.00 \\
\hline 14 & $\begin{array}{l}\text { A foreign manager does not reflect his/her personal problems on his/her way of } \\
\text { treating his/her employees }\end{array}$ & 2.9200 & 0.85 & 3.480 & 0.001 \\
\hline 15 & $\begin{array}{l}\text { A foreign manager uses some methods to break the daily routine and entertain the } \\
\text { employees }\end{array}$ & 2.9400 & 0.93 & 3.328 & 0.002 \\
\hline 17 & A foreign manager encourages the successful and effective employees & 3.0000 & 0.75 & 4.677 & 0.00 \\
\hline 18 & The foreign manager seeks to develop entertainment programs for employees & 2.9600 & 0.53 & 6.103 & 0.00 \\
\hline 19 & Work cyclicity low in the foreign rates manager & 2.5600 & 0.90 & 0.468 & 0.642 \\
\hline 23 & A foreign manager encourages effective participation & 2.8800 & 0.65 & 4.077 & 0.00 \\
\hline 25 & A foreign manager views employees positively & 3.0800 & 0.63 & 6.471 & 0.00 \\
\hline \multirow[t]{2}{*}{29} & I prefer working with a foreign manager & 2.4200 & 0.90 & 0.625 & 0.535 \\
\hline & Total & 2.8954 & 0.53 & 5.213 & 0.00 \\
\hline
\end{tabular}

Fifth Question: How much efficiency do foreign managers have?

According to table number 6, it appears that all of the questions had a mean that is above 2.5 and a level of accuracy that is less than 0.05 , except for column (question) 28. This means that all of these columns are statistically significant and are present in foreign managers. Column 28, however, had a mean that is above 2.5 but its level of accuracy was above 0.05 , which means it is not statistically significant, and there is no significance level about the fact that if a problem happened between you and your foreign manager, your foreign manager would try to solve it wisely and gently. The total of the columns had a mean of 2.98 and a level of accuracy that was 0.00 . This level is less than 0.05 therefore foreign managers are efficient.

Table 6. Mean, standard deviation, t-value and accuracy level of efficiency in foreign managers

\begin{tabular}{|c|c|c|c|c|c|}
\hline Question Number & Question & Mean & Standard Deviation & T-Value & Accuracy Level \\
\hline 3 & Foreign manager knows the details of the work of his employees. & 2.9600 & 0.87 & 3.697 & 0.001 \\
\hline 5 & Foreign manager is able to make the correct decisions at the right time & 2.9400 & 0.68 & 4.559 & 0.00 \\
\hline 11 & $\begin{array}{l}\text { Foreign manager is able to come up with new ideas and discuss them with its } \\
\text { employees }\end{array}$ & 3.0800 & 0.69 & 5.900 & 0.00 \\
\hline 13 & A foreign manager improves the employees always by training them & 3.0800 & 0.80 & 5.101 & 0.00 \\
\hline 20 & $\begin{array}{l}\text { A foreign manager supports any employees in need of financial or emotional } \\
\text { support }\end{array}$ & 2.8200 & 0.84 & 2.663 & 0.01 \\
\hline 21 & A foreign manager helps to develop the ideas of employees & 3.1200 & 0.71 & 6.104 & 0.00 \\
\hline 24 & Effective leadership make the employees achieve the goals of hotel & 3.0400 & 0.78 & 4.886 & 0.00 \\
\hline 26 & A foreign manager makes predictions about future & 2.9600 & 0.72 & 4.472 & 0.00 \\
\hline 27 & $\begin{array}{l}\text { Foreign manager knows the bases and concepts of quality in the hotel he/she } \\
\text { manage }\end{array}$ & 3.0800 & 0.75 & 5.457 & 0.00 \\
\hline \multirow[t]{2}{*}{28} & $\begin{array}{l}\text { If a problem happened between you and your foreign manager, he/she would } \\
\text { try to solve it wisely and gently }\end{array}$ & 2.7400 & 0.96 & 1.759 & 0.085 \\
\hline & Total & 2.9820 & 0.56 & 6.019 & 0.00 \\
\hline
\end{tabular}

Sixth Question: How many skills do foreign managers have?

According to table number 7, it appears that all of the columns had a mean that is above 2.5 and a level of accuracy that is less than 0.05 . This means that all of these columns are statistically significant and are present in foreign managers. The total of the columns had a mean of 3.01 and a level of accuracy that was 0.00 . This level is less than 0.05 therefore foreign managers are skilled.

Table 7. Mean, standard deviation, t-value and accuracy level of skills in foreign managers

\begin{tabular}{|c|l|c|c|c|c|}
\hline Question Number & \multicolumn{1}{|c|}{ Question } & Mean & Standard Deviation & T-Value & Accuracy Level \\
\hline 2 & A foreign manager is able to deal with its employees directly & 2.7200 & 0.92 & 1.679 & 0.00 \\
\hline 6 & A foreign manager takes the opinions and ideas of employees seriously & 3.1200 & 0.68 & 6.854 & 0.00 \\
\hline 10 & A foreign manger respects the customs and traditions of domestic employees & 3.1600 & 0.61 & 7.550 & 0.00 \\
\hline 12 & $\begin{array}{l}\text { A foreign management keeps up with technology and opens new } \\
\text { opportunities associated with the new technology }\end{array}$ & 3.0600 & 0.76 & 5.163 & 0.00 \\
\hline 16 & A foreign manager encourages employees to advance academically & 2.9400 & 0.68 & 4.559 & 0.00 \\
\hline 22 & A foreign manager manages his/her time wisely and is able to cope with stress & 3.0400 & 0.60 & 6.314 & 0.00 \\
\hline & Total & 3.01 & 0.50 & 6.019 & 0.00 \\
\hline
\end{tabular}

Seventh Question: Are there any statistically significant differences between the behavior of domestic and foreign managers?

According to table number 8 , it is clear that the difference between the behavior of domestic and foreign managers is 0.055 , and that foreign managers have better behavior than the locals. However, this difference is not statistically significant because the level of accuracy 
has reached 0.56 and it is above 0.05 . Therefore, there are no statistically significant differences between the behavior of domestic and foreign managers.

Eighth Question: Are there any statistically significant differences between the skills of domestic and foreign managers?

Depending on table number 8, the statistically significant difference between the skills of domestic and foreign managers is 0.050 and that foreign managers have better skills than the domestics. However, this difference is not statistically significant because the level of accuracy has reached 0.65 and it is above 0.05 . Therefore, there are no statistically significant differences between the skills of domestic and foreign managers.

Ninth Question: Are there any statistically significant differences between the efficiency of domestic and foreign managers?

Depending on table 8 again, the difference between the efficiency of domestic and foreign managers was 0.14 and that domestic managers are more efficient than foreign managers. However, this difference is not statistically significant because the level of accuracy has reached 0.412 and it is above 0.05 . Therefore, there are no statistically significant differences between the efficiency of domestic and foreign managers.

Table 8. Examining the difference between the behavior, efficiency and skills of domestic and foreign managers

\begin{tabular}{|c|c|c|c|c|c|c|}
\hline \multicolumn{2}{|c|}{ Behaviour of Foreign } & \multicolumn{2}{c|}{ Efficiency of Foreign } & \multicolumn{2}{c|}{ Skills of Foreign } \\
\hline \multicolumn{2}{|c|}{ Statistically Significant } & Difference & Statistically Significant & Difference & Statistically Significant & Difference \\
\hline Behaviour of domestics & 0.56 & -0.055 & & & & \\
\hline Efficiency of Domestics & & & & -0.050 & & \\
\hline Skills of Domestics & & & 0.65 & & & 0.412 \\
\hline
\end{tabular}

*Difference $=$ vertical - horizontal

\section{CONCLUSION}

This paper focuses on behavior, skills, efficiency, and the differences between foreign and domestic managers in five and four star hotels in Jordan. According to the results there is no big difference between the number of males and females in the hotels of the study sample. This indicates that females are knowledgeable and well aware of tourism and that is what motivated them to work in the hospitality sector. Most of the respondents had bachelor degrees and this is evidence that their responses were realistic and accurate. The behavior of the domestic managers is positive. Moreover, the domestic managers have efficiencies, management skills and the abilities to accomplish and achieve success. The foreign language is a barrier between employees and managers because foreign managers rarely speak Arabic. Thus, this is a very serious indication about whether or not the employees understand and follow the instructions and guidelines of their managers. However, there is no statistically significant difference between the behavior, skills, and efficiency of domestic and foreign managers.

Finally, there is no difference between foreign and domestic managers to manage the operational departments in five and four star hotels. Therefore, the authorities must adopt a training program suitable for all groups in the hotel departments in order to prepare for the replacement of domestic workers with the place of the foreigner in managing the departments in order to avoid all the challenges that have been mentioned by: Baert and Verhaest (2019); Abo-Murad and Abdullah (2019); Dyer and Batnitzky (2010); Khaleefah et al. (2018); Patunru and Uddarojat (2015).

\section{RECOMMENDATIONS}

The findings of this study suggest that Hotel management needs to address the deficient management of the domestic managers of their personal problems and the effects of them being reflected on his/her job and treatment of employees. This deficient management may cause the employees to become unsatisfied and disappointed and it could reflect on their performance in their jobs. The manager should be aware of the significance of social communications and its effect on the behavior and attitude of his/her employees. For this purpose (Vance and Paik, 2015) said; he/she should treat the employees in a friendly and welcoming manner and stay away from arrogance and conceit; especially outside of working hours, this would make the employees respect and admire their manager and it would reflect positively on their jobs. Another issue that needs to be studied in an independent study is to not favor the study sample of employees to work with the domestic manager because this would imply the presence of obstacles between excepting to work with the domestic manager. Therefore, this rejection should be analyzed by taking a look at its causes and motivations as soon as possible. Hotel management should be aware of the significance of clear understanding of the foreign management, therefore, employees face difficulties in understanding exactly what the foreign management wants and usually the foreign management is ignorant of the internal and external environments of the country despite its studies and analyses. This includes customs and traditions of the country requirements, and behaviors' of the domestic employees and customers, governmental laws, etc. The researchers recommend tourism ministry, labor office, national centre for human resources development and hotel associations to organize trainings for the domestic managers with deep knowledge and experience inside and outside of the country to make them qualified to manage hotels and work to international levels. The researchers suggest that the five and four star hotels managers to give the opportunities for departments managements' to Jordanians managers to establish their selves as being skilled, efficient and talented and that other sectors of Jordan to conduct researches like this research to find the strong and weak spots of the local employees in comparison to the foreign employees. Also, try to work on the weak spots of the local employees and try to fix them; so that the local employees would take over the job positions of the foreign management and employees.

\section{IMPLICATIONS}

This study has practical implications for decision-makers and owners of tourism companies in the Arab world, especially hotels, thereof the results of the study recommend that there is no difference in the capabilities of the domestic manager for the foreign manager in managing work for five and four-star hotels and the reasons have been mentioned, and most of which it was positive by virtue of the rapprochement between the customs and traditions of the domestic manager and the rest of the domestic hotel staff. As it is possible to understand the needs and desires of employees by the domestic manager more than other foreigners.

Here the problem lies in the inability of the parties (domestic staff and the foreign manager) to understand each other due to differences (language, customs, traditions, discipline, religion, etc.), it is not reasonable to seek the assistance of foreign competencies that manage the work according to the policies of foreign countries and are not able to deal and contact with staffs need and desire in order to manage work and enhance the success for the hotel. There are some simple things that the domestic manager understands because he is from the same employee community, and he deals with it according to the facts of the societal reality in which he lives, this understanding of these matters 
creates bridges of communication and respect between theme, while it is difficult for the foreign manager to understand the Arab community and its customs and traditions Accurately and correctly.

As for management capabilities and skills, the local manager can be developed and prepared within training and development plans that enable him to achieve knowledge, skills, and attitude (KSA), so that he is able to create a twinning in behavioral interaction with employees on the one hand and getting managing hotel work success within the requirements of successful management on the other. This is what (Fang et al., 2010; Abo-Murad and Abdullah, 2019; Baum, 2019; Kale, 2020) focused on.

\section{RESEARCH LIMITATIONS AND FUTURE DIRECTIONS}

Some of the results of this study may represent slightly biased views in favor of the domestic manager, which leads us to develop proposals for future research related to measuring the views of foreign managers during their service and experience working in hotels within the Arab world, and determine challenges (work, society, employees, a clear understanding of customs, Religion, and human relationships, etc.) that encountered theme while working to study them broadly and individually.

The questionnaire was designed by drawing on the previous literature with a focus on the most important variables related to the current study, and researchers can study variables and other factors related to the study and from different dimensions of foreign employment, including the economic dimension, security dimension, societal dimension, knowledge dimension, and others, and the application of these variables to hotels and other different sectors.

\section{REFERENCES}

Abo-Murad, M., \& Abdullah, A.K. (2019). Turnover culture and crisis management: Insights from Malaysian hotel industry. Academy of Strategic Management Journal, 18(2), 1-14.

Alaak, B. (1999). The foundations of modern management, Dar Yazouri publishing, Amman.

Ashley, C., \& Roe, D. (2002). Making tourism work for the poor: strategies and challenges in southern Africa. Development Southern Africa, 19(1), 61-82.

Baert, S., \& Verhaest, D. (2019). Unemployment or overeducation: which is a worse signal to employers? De Economist, 167(1), 1-21.

Baum, T. (2019). Hospitality employment 2033: A backcasting perspective (invited paper for 'luminaries' special issue of international journal of hospitality management). International Journal of Hospitality Management, 76, 45-52.

Bloom, N., \& Van Reenen, J. (2010). Why do management practices differ across firms and countries? Journal of economic perspectives, $24(1), 203-24$.

Deisler, G. (1991). Basicsof Management, Mars Publishing House, Kingdom of Saudi Arabia.

Denisi, A.S., \& Griffin, R.W. (2005). Human Resources Management, Mc Graw-Hill, Inc, USA.

Dyer, S., McDowell, L., \& Batnitzky, A. (2010). The impact of migration on the gendering of service work: The case of a West London hotel. Gender, Work \& Organization, 17(6), 635-657.

Dunning, J.H., \& Lundan, S. (2008). Multinational enterprises and the global economy, Cheltenham: Edward Elgar.

Fang, Y., Jiang, G.L.F., Makino, S., \& Beamish, P.W. (2010). Multinational firm knowledge, use of expatriates, and foreign subsidiary performance. Journal of Management Studies, 47(1), 27-54.

Ferraris, A., Santoro, G., \& Dezi, L. (2017). How MNC's subsidiaries may improve their innovative performance? The role of external sources and knowledge management capabilities. Journal of Knowledge Management, 21(3), 540-552.

Fu, X., Helmers, C., \& Zhang, J. (2012). The two faces of foreign management capabilities: FDI and productive efficiency in the UK retail sector. International Business Review, 21(1), 71-88.

Gooze, J. (1991). The Elusive Concept of Efficiency in Education, Faculty of Education, USA. http://www.mun.ca/educ/faculty/mwatch/vol1/cooze.html.

Haendel, D. (2019). Foreign investments and the management of political risk. Routledge.

Hashim, M.Z. (1989). Human resources management, with chains for printing and publishing, Kuwait.

Hoffman, K. (2019). Driving force: the global restructuring of technology, labor, and investment in the automobile and components industry. Routledge.

Hujaz, M. (2004). Management of Hotel Organization, Taybah for publishing, Amman-Jordan.

Jumaily, Q. (2015). Human Resources Management in tourism and Hotel Intuition, Al Muataz for Publishing, Amman-Jordan.

Kale, E. (2020). Attachment styles and job performance in the hospitality industry: the mediating role of general self-efficacy. Journal of Human Resources in Hospitality \& Tourism, 19(1), 23-42.

Qusay, Q., Jawabreh, O., Bashar, M., \& Rami, M. (2018). Why Arab societies do not encourage the work of their members in hotels. Modern Applied Science, 12(11). DOI: 10.5539/mas.v12n11p259.

Linehan, M. (2019). Senior female international managers, Routledge, book.

Manoharan, A., Sardeshmukh, S.R., \& Gross, M.J. (2019). Informal diversity management practices and their effectiveness: In the context of ethnically diverse employees in hotels. International Journal of Hospitality Management, 82, 181-190.

Murthy, D.B.N. (2003). Managing Human Resources, UBS publishers, New Delhi.

Naschold, F. (2017). New Frontiers in the Public Sector Management: Trends and Issues in State and Local Government in Europe (Vol. 69). Walter de Gruyter $\mathrm{GmbH} \& \mathrm{Co} \mathrm{KG}$.

Palthe, J. (2004). The relative importance of antecedents to cross-cultural adjustment: Implications for managing a global workforce. International Journal of Intercultural Relations, 28(1), 37-59.

Patunru, A., \& Uddarojat, R. (2015). Reducing the financial burden of Indonesian migrant workers, CIPS Policy Recommendations, (1).

Richards, A., \& Martin, P.L. (1983). The laissez-faire approach to international labor migration: The case of the Arab Middle East. Economic Development and Cultural Change, 31(3), 455-474.

Rumi, N., bin Hishal, A., \& Farajy, A. (2005-2006). Material characterization of vocational education in the plan of the new school for secondary education, Ministry of Education, Department of Secondary Education, Kingdom of Saudi Arabia.

Sweilem, M. (1991). Principles of Management, Arab Renaissance Publishing House, Cairo.

Te Velde, D., \& Morrissey, O. (2002). Foreign direct investment, skills and wage inequality in East Asia, Presented at the DESG conference.

Torrigton, D. (2002). Human Resources Management, $5^{\text {th }}$, Hall Europe, U.K.

Vance, C.M., \& Paik, Y. (2015). Managing a global workforce. Routledge.

Werther, W. (1996). Human Resources \& Personnel Management, $5^{\text {th }}$ Mc Graw-Hill, Inc, USA

Woods, R.H. (1995). Human Resources Management, $2^{\text {th }}$ Educational Institute of American Hotel and Motel Association, USA.

$\mathrm{Xu}$, H., Guo, H., Zhang, J., \& Dang, A. (2018). Facilitating dynamic marketing capabilities development for domestic and foreign firms in an emerging economy. Journal of Business Research, 86, 141-152.

Zaheer, S., Lamin, A., \& Subramani, M. (2009). Cluster capabilities or ethnic ties? Location choice by foreign and domestic entrants in the services offshoring industry in India. Journal of International Business Studies, 40(6), 944-968.

*** Chairman of the Labor, Social Development and Population Committee, Jordan News Agency, Betra. http://petra.gov.jo/Include/InnerPage.jsp? ID=71409\&lang=en\&name=news.

*** Ministry of Tourism \& Antiquities, Jordan (2019). https://www.mota.gov.jo/DefaultAr.aspx. 